\title{
Reforço Escolar nos Anos Finais do Ensino Fundamental Mediante a Inclusão no Projeto Político-Pedagógico
}

\author{
Apoyo Pedagógico en la Final de Años de Educación Básica a través de la \\ Inclusión en el Proyecto Pedagógico
}

\author{
Leandro Jacques Martins ${ }^{1}$ \\ ${ }^{1}$ leandrojacquesmartins@ hotmail.com, Faculdade Educacional da Lapa.
}

\begin{abstract}
Resumo
Os relatórios produzidos pelo Ministério da Educação, a partir dos resultados da Prova Brasil, aplicada aos alunos da $8^{\mathrm{a}}$ série $/ 9^{\circ}$ ano nas disciplinas de Língua Portuguesa e Matemática demonstram as dificuldades de aprendizagem dos estudantes brasileiros nessas áreas. Os resultados da Prova Brasil aplicada em 2013 demonstraram que em Língua Portuguesa apenas 28,7\% dos estudantes concluem o ensino fundamental com aprendizado adequado e em Matemática esse índice cai para 16,4\%. A legislação educacional brasileira determina padrão mínimo de qualidade na educação e a obrigatoriedade de estudos de recuperação para alunos com dificuldades de aprendizagem. Diversos autores e a própria legislação estabelecem a necessidade da ampliação do tempo e do espaço pedagógico. O reforço escolar, mediante a inclusão no projeto políticopedagógico da escola, configura-se numa alternativa importante no enfrentamento às dificuldades de aprendizagem em Língua Portuguesa e Matemática. A fim de se conhecer as dificuldades enfrentadas pelos professores de Língua Portuguesa e Matemática dos anos finais do ensino fundamental e a adoção de reforço escolar por parte das escolas, realizou-se entrevistas com docentes dessas duas áreas do conhecimento que atuam em duas escolas da rede pública de Barra do Quaraí.
\end{abstract}

Palavras-Chave: Dificuldades, Aprendizagem, tempo, espaço, educação.

\section{Introdução}

O Ministério da Educação instituiu no ano de 2007 a avaliação denominada Prova Brasil, a fim de avaliar os conhecimentos (habilidades e competências) dos estudantes do ensino fundamental nas disciplinas de Língua Portuguesa e Matemática e medir a qualidade da educação pública brasileira.

Os resultados dessa avaliação têm demonstrado as dificuldades dos alunos dos anos finais do ensino fundamental $\left(8^{\mathrm{a}}\right.$ série $/ 9^{\circ}$ ano $)$ nas disciplinas de Língua Portuguesa e Matemática.

Infelizmente, percebe-se que as ações pedagógicas organizadas pelas escolas e destinadas à superação das dificuldades de aprendizagem se resumem a ações tradicionais centradas dentro de um espaço e tempo delimitado ao período regular de aula.

"Não podemos esquecer que a escola precisa achar meios de oferecer espaços e tempos de aprendizagem de qualidade" (ROSS, p.23) e uma estratégia eficaz para melhorar o rendimento escolar é a oferta de reforço escolar em contraturno, mediante a inclusão no projeto político-pedagógico da escola.

Aliás, "podemos encontrar alunos que têm suas dificuldades resolvidas com atividades de reforço escolar simplesmente" (Estratégias e Orientações para a Educação com Alunos 
com Dificuldades Acentuadas de Aprendizagem Associadas às Condutas Típicas, 2002, p.33), demonstrando a relevância dessa estratégia pedagógica.

Em entrevista realizada com professores de Língua Portuguesa e Matemática, dos anos finais do ensino fundamental de duas escolas da rede pública da cidade de Barra do QuaraíRS, verificou-se, que mesmo havendo apenas três escolas, ocorrem problemas semelhantes aos constatados em nível nacional como falta de ações eficientes e eficazes por parte do Poder Público para melhorar a qualidade da educação no município e problemas na gestão das escolas.

\section{Desenvolvimento}

Na cidade de Barra do Quaraí-RS, localizada na fronteira oeste do Rio Grande do Sul, realizou-se entrevistas com professores de Língua Portuguesa e Matemática dos anos finais do ensino fundamental em duas escolas da rede pública sobre as dificuldades de aprendizagem dos estudantes e a adoção do reforço escolar, mediante a inclusão no projeto políticopedagógico das escolas.

Ressalta-se que os professores entrevistados pertenciam a duas escolas da rede pública: uma escola municipal e outra estadual - ambas do perímetro urbano e que concentram juntas quase que $92 \%$ do total dos estudantes matriculados no ensino fundamental na cidade.

Constatou-se que, no projeto político-pedagógico da escola municipal, consta a oferta de reforço escolar para os alunos dos anos finais, contudo o Poder Público Municipal não efetivou (autorizou) ainda essa ação e na escola da rede pública estadual tal medida não está contemplada no projeto político-pedagógico.

A partir da análise das respostas dos professores na entrevista, percebeu-se que muitos alunos ingressam nos anos finais do ensino fundamental sem os conhecimentos mínimos exigidos, além disso os docentes citaram que há uma cobrança excessiva aos mesmos por resultados positivos.

Evidenciou-se ainda o reconhecimento dos professores sobre a importância do reforço escolar para o enfrentamento das dificuldades de aprendizagem dos estudantes de Barra do Quaraí, ressaltando que todos manifestaram interesse em ministrar aulas de reforço escolar aos estudantes com dificuldades de aprendizagem.

\section{Considerações Finais}

"Ensinar não é transferir conhecimentos, mas criar as possibilidades para sua produção ou a sua construção" (FREIRE, 1996, p.12), ora se o estudante apresenta dificuldades aprendizagem em disciplinas fundamentais para o prosseguimento dos estudos e para o acesso ao mundo do trabalho e à cidadania, impõe-se a necessidade urgente da construção de estratégias e ações que realmente contribuam para amenizar o problema.

Apesar dos dados demonstrarem as dificuldades de aprendizagem dos estudantes dos anos finais do ensino fundamental em Língua Portuguesa e Matemática, as ações para o enfrentamento ao problema ainda estão atreladas a um tempo e a um espaço limitado, ou seja, restrito ao período regular em sala de aula sem que se pense uma nova estratégia que contribua para a superação das dificuldades de aprendizagem dos estudantes: 
...os professores/as com grupos pequenos podem proporcionar mais atenção aos estudantes, dispor de um clima para um melhor conhecimento com estes, adquirindo mais economia em tempo e em gestão da classe; podem se desenvolver com mais facilidades diferentes atividades... (SACRISTÁN E GÓMEZ, 2007, p. 262)

Com relação às escolas públicas de Barra do Quaraí, a resposta dos professores de Língua Portuguesa e Matemática sobre os problemas enfrentados, a carga de cobrança em cima dos docentes por resultados positivos e a falta de conhecimentos mínimos por parte dos alunos, por exemplo, demonstram a necessidade urgente de ações efetivas por parte do Poder Público e dos gestores escolar.

Aliás, com relação à gestão nas escolas, evidenciou-se a necessidade de medidas concretas por parte dos gestores escolares, a fim de melhorar a qualidade da educação, pois, afinal, "o fim último da gestão escolar é a aprendizagem efetiva e significativa dos alunos" (LÜCK, 2009, p. 25)

A adoção de reforço escolar que conta com o apoio dos professores de Língua Portuguesa e Matemática associado ao número reduzido de alunos nas escolas de Barra do Quaraí certamente contribuiria para a melhoria da qualidade da educação no município.

Libâneo (1994) declara que "os resultados da aprendizagem se manifestam em modificações na atividade externa e interna do sujeito, nas suas relações com o ambiente físico e social", por isso o enfrentamento às dificuldades de aprendizagem de nossos estudantes deve ser considerado como garantia à dignidade e a uma educação de qualidade.

\section{Referências}

ARROYO, Miguel G. Imagens Quebradas: trajetórias e tempos de alunos e mestres. Petrópolis: Vozes, 2011.

BRASIL. Estratégias e Orientações para a Educação de Alunos com Dificuldades Acentuadas de Aprendizagem Associadas às Condutas Típicas. Brasília: MEC/SEESP, 2002.

FREIRE. PAULO. Pedagogia da Autonomia. São Paulo: Paz e Terra, 2002.

LIBÂNEO, José Carlos. Didática. São Paulo: Cortez, 1994.

LÜCK, Heloísa. Dimensões da Gestão Escolar e Suas Competências. Curitiba: Positivo, 2009.

SACRISTÁN, J. Gimeno; GÓMEZ, A.I. Pérez. Compreender e Transformar o Ensino. São Paulo: Artmed, 1998

ANA PAULA ROSS. Sobre a (in)Governabilidade da Diferença. Inclusão Escolar: conjunto de práticas que governam, Belo Horizonte, p. 23-28, 2009. 
DE OLHO NAS METAS 2013-2014. Sexto Monitoramento das 5 Metas do Todos pela Educação. Disponível em:

http://www.todospelaeducacao.org.br//arquivos/biblioteca/de_olho_nas_metas_2013_141.pdf $>$ Acesso em: 29 junho 2015.

http://portal.inep.gov.br/web/saeb/aneb-e-anresc 